\title{
Studi Tentang Learning Style Peserta Didik pada Bidang Studi IPA Terpadu
}

\author{
Jefrianto $^{* 1}$, Sainab ${ }^{2}$ \\ ${ }^{1,2}$ Universitas Sulawesi Barat \\ e-mail : ' aryanto.jeff@gmail.com, ${ }^{2}$ sainabruddin@gmail.com
}

\begin{abstract}
Abstrak
Jenis penelitian ini adalah penelitian deskriptif dengan metode studi kasus (survey). Penelitian ini memuat uraian tentang learning style (Visual, Auditorial dan Kinestetik). Dalam penelitian ini ditemukan jawaban bahwa terdapat keragaman gaya belajar peserta didik pada bidang studi IPA Terpadu kelas VIII SMPN 6 Majene. Populasi dalam penelitian ini sekaligus menjadi sampel dengan menggunakan sampling jenuh yang berjumlah 44 orang peserta didik. Hasil penelitian menunjukkan bahwa gaya belajar peserta didik pada bidang studi IPA Terpadu kelas VIII SMP Negeri 6 Majene secara keseluruhan menunjukkan gaya belajar visual yang paling banyak digunakan peserta didik yaitu sebesar 54\%, gaya belajar kinestetik sebesar 26\% dan gaya belajar auditorial sebesar $20 \%$.
\end{abstract}

Kata kunci : Learning Style, penelitian deskriptif, IPA Terpadu

\section{PENDAHULUAN}

Secara umum prestasi belajar peserta didik di Indonesia ditentukan oleh kemampuan kognitifnya dalam memahami sebaran materi pelajaran yang telah ditentukan kurikulum.Tingkah laku kognitif merupakan tindakan mengenal atau memikirkan situasi dimana tingkah laku terjadi. Dengan demikian struktur kognitif sebagai hasil belajar yang diperoleh peserta didik mempunyai bentuk yang beraneka ragam Sardiman (2014).

Selanjutnya pendidikan memegang peranan penting dalam mempersiapkan sumber daya manusia yang berkualitas. Oleh karena itu pendidikan hendaknya dikelolah baik secara kualitas maupun kuantitas. Hal tersebut bisa tercapai bila peserta didik dapat menyelesaikan materi dengan hasil belajar yang baik. Hasil belajar seseorang ditentukan oleh berbagai faktor yang mempengaruhinya. Salah satu faktor yang ada di luar individu adalah tersedianya bahan ajar yang memberi kemudahan bagi individu untuk mempelajarinya, sehingga menghasilkan hasil belajar yang lebih baik. Selain itu juga gaya belajar atau learning style adalah suatu karakteristik kognitif, afektif dan perilaku psikomotoris, sebagai indikator bertindak yang relatif stabil untuk peserta didik merasa saling berhubungan dan bereaksi terhadap lingkungan belajar. Gaya belajar mengacu pada cara belajar yang lebih disukai peserta didik. Umumnya dianggap bahwa gaya belajar seseorang berasal dari variabel kepribadian, termasuk susunan kognitif dan psikologis, latar belakang sosial kultural serta pengalaman pendidikan Sardiman (2014).

Keanekaragaman gaya belajar peserta didik perlu diketahui sejak awal pendidikan. Hal ini akan memudahkan bagi peserta didik untuk belajar maupun guru dalam proses pembelajaran. Peserta didik akan dapat belajar dengan baik dan hasil belajarnya baik, apabila ia mengerti gaya belajarnya. Hal ini memudahkan peserta didik dapat menerapkan pembelajaran dengan mudah dan tepat. 
Peserta didik pada bidang studi IPA terpadu kelas VIII SMPN 6 Majene memiliki kegiatan belajar yang beragam. Kegiatan belajar ini menuntut peserta didik menggunakan gaya belajarnya secara optimal sehingga tercapai hasil yang efektif. Penelitian mengenai gaya belajar peserta didik belum pernah dilakukan di SMPN 6 Majene. Berdasarkan observasi awal yang dilakukan penulis, peserta didik pada bidang studi IPA terpadu kelas VIII SMPN 6 Majene belum memahami gaya belajarnya masing-masing sehingga belum dapat memaksimalkannya dalam proses belajar. Ditemukan juga gaya belajar peserta didik yang beragam. Oleh karena itu, perlu diteliti secara mendalam gaya belajar dari masing-masing peserta didik. Sebagai bahan masukan terdapat penelitian serupa yang pernah dilakukan oleh Wulandari (2015) dengan hasil penelitian yang menerangkan bahwa terdapat tiga macam gaya belajar pada peserta didik kelas XI di SMA Negeri 1 Kota Jambi yaitu gaya belajar auditorial paling banyak digunakan peserta didik, kemudian gaya belajar visual dan gaya belajar kinestetik digunakan peserta didik yang persentasenya paling rendah.

\section{METODE PENELITIAN}

Pada penelitian ini digunakan jenis penelitian deskriptif dengan metode studi kasus (survey). Metode survey adalah penelitian yang mengambil sampel dari satu populasi dan menggunakan kuesioner sebagai alat pengumpulan data-data pokok yang diperlukan. Penelitian deskriptif adalah prosedur penelitian yang menghasilkan data berupa data tertulis atau lisan dari orang-orang dan perilaku yang dapat diamati Zuriah (2010). Penelitian ini dilaksanakan pada semester genap tahun ajaran 2015/2016. Subjek penelitian ini adalah pendidik kelas VIII dan Kepala Sekolah SMP Negeri 6 Majene, sebagai subyek yang membantu dalam perencanaan dan pengumpulan data penelitian. Sedangkan seluruh peserta didik Kelas VIII SMP Negeri 6 Majene sebagai objek penelitian. Peneliti sendiri sebagai subjek yang bertugas merencanakan, mengumpulkan data, menganalisis data, dan membuat kesimpulan penelitian.

\subsection{Teknik Pengumpulan Data}

Untuk mendapatkan data yang diperlukan dalam penelitian, maka digunakan teknik observasi, dokumentasi, dan angket. Dalam hal ini, peneliti melakukan pengumpulan data melalui 3 tahapan, yaitu :

\subsubsection{Tahap persiapan.}

Tahap persiapan ini, peneliti melakukan studi pendahuluan tentang keadaan belajar mengajar di sekolah (yang telah dijadikan sebagai objek penelitian). Setelah itu, peneliti melanjutkan studi pustaka yang ada hubungannya dengan tipe belajar. Selanjutnya, peneliti menyusun instrumen berupa angket atau daftar pertanyaan untuk diberikan kepada responden/peserta didik.

\subsubsection{Tahap Pengumpulan Data}

Pada tahap ini peneliti mengadakan penelitian lapangan dengan mengadakan observasi atau pengamatan langsung pada objek penelitian kemudian membagikan angket pada Peserta didik Kelas VIII SMP N 6 Majene yang menjadi sampel penelitian.

\subsubsection{Tahap pengelolaan data}

Setelah peneliti memperoleh data dari objek yang diteliti selanjutnya peneliti mengolah data tersebut sebagai hasil dan pembahasan dalam penelitian ini. Margono (2010) menjelaskan bahwa untuk memperoleh persentase dari skor jawaban kuesioner 
yang telah didapatkan, dilakukan penghitungan dengan menggunakan rumus sebagai berikut:

$$
P=\frac{f}{n} \times 100 \%
$$

Keterangan :

$P \quad=$ Persentase gaya belajar peserta didik

$f \quad=$ Frekuensi jawaban peserta didik

$n \quad=$ Banyaknya peserta didik

\subsection{Teknik Analisis Data}

Pada tahapan analisis data dilakukan proses penyederhanaan data-data yang terkumpul ke dalam bentuk yang lebih mudah dibaca dan dipahami. Tahapan analisis data yang dilakukan peneliti yaitu:

1. Pengumpulan Data

Pengumpulan data dilakukan melalui cara observasi, dokumentasi dan kuesioner/angket. Pada tahapan ini data-data yang sudah terkumpul dibuatkan transkripnya, yakni dengan cara menyederhanakan informasi yang terkumpul ke dalam bentuk tulisan yang mudah dipahami. Setelah itu data-data yang terkumpul dipilih sesuai dengan fokus penelitian ini dan diberi kode untuk memudahkan peneliti dalam mengkategorikan data-data yang terkumpul.

2 Reduksi Data

Pada tahapan ini, data-data yang sudah diberi kode dan sudah dikelompokkan dirangkum untuk memberikan gambaran yang lebih jelas.

3. Penyajian Data

Data yang sudah terangkum ditafsirkan dan dijelaskan untuk menggambarkan keadaan learning style atau gaya belajar peserta didik pada bidang studi IPA Terpadu kelas VIII SMPN 6 Majene. Penyajian data yang sudah ditafsirkan dan dijelaskan berbentuk uraian dengan teks atau bersifat naratif.

4. Penarikan Kesimpulan

Pada tahap ini peneliti menarik kesimpulan dari hasil analisis data yang sudah dilakukan. Penarikan kesimpulan dalam penelitian mungkin dapat menjawab rumusan masalah yang dirumuskan sejak awal.

\section{HASIL DAN PEMBAHASAN}

\subsection{Hasil Penelitian}

Data pada penelitian ini diperoleh dengan menyebarkan kuesioner kepada responden yaitu peserta didik bidang studi IPA terpadu kelas VIII SMPN 6 Majene. Pendistribusian kuesioner dilakukan dengan mendatangi secara langsung SMPN 6 Majene yang menjadi lokasi pengambilan sampel dan membagikannya kepada responden. Proses pendistribusian hingga pengumpulan data dilakukan kurang lebih selama satu minggu yaitu dari tanggal 14 April hingga 20 April 2016. Kuesioner yang dibagikan kepada sampel penelitian sebanyak 44 eksamplar. Rincian pendistribusian kuesioner tersebut dapat dilihat pada tabel 1 berikut ini. 
Tabel 1 Ikhtisar Distribusi dan Pengembalian Kuesioner

\begin{tabular}{|c|l|c|c|}
\hline No. & \multicolumn{1}{|c|}{ Keterangan } & Jumlah Kuesioner & Persentase \\
\hline 1 & Distribusi kuesioner & 44 & $100 \%$ \\
\hline 2 & $\begin{array}{l}\text { Kuesioner yang tidak } \\
\text { kembali }\end{array}$ & 3 & $6,8 \%$ \\
\hline 3 & Kuesioneryang kembali & 41 & $93 \%$ \\
\hline 4 & Kuesioner yang cacat & 6 & $13,6 \%$ \\
\hline 5 & $\begin{array}{l}\text { Kuesioner yang dapat } \\
\text { diolah }\end{array}$ & 35 & $80 \%$ \\
\hline
\end{tabular}

Sumber: Data primer ( 2016)

Data tabel 1 menunjukkan bahwa kuesioner yang didistribusikan adalah sebanyak 44 eksamplar. Sedangkan tingkat kuesioner yang tidak kembali adalah 3 atau sebanyak $7 \%$. Total kuesioner yang kembali ini adalah $93 \%$ atau sebanyak 41. Dari keseluruan kuesioner yang kembali, tidak semuanya digunakan dalam tahap analisis. Setelah dilakukan proses penyuntingan, terdapat enam kuesioner yang gugur karena tidak lengkap atau tidak diisi.

Berdasarkan penelitian yang dilakukan pada 44 peserta didik bidang studi IPA Terpadu kelas VIII SMPN 6 Majene yang terbagi dalam kelas VIII A sebanyak 21 orang dan kelas VIII B sebanyak 23 orang diperoleh hasil yang disajikan pada tabel 2 berikut.

Tabel 2 Gaya Belajar Peserta Didik Pada Bidang Studi IPA Terpadu

\begin{tabular}{|c|c|c|c|}
\hline NO. & Gaya Belajar & Ferukensi & Persentase \\
\hline 1. & Visual & 12 & $34 \%$ \\
\hline 2. & Auditorial & 5 & $14 \%$ \\
\hline 3. & Kinestetik & 7 & $20 \%$ \\
\hline 4. & Mix 1 (Visual-Auditorial) & 3 & $9 \%$ \\
\hline 5. & Mix 2 (Visual- Kinestetik ) & 5 & $14 \%$ \\
\hline 6. & Mix 3 ( Auditorial - kinestetik) & 1 & $3 \%$ \\
\hline 7. & Mix 4 (Visual-Auditorial-Kinestetik) & 2 & $6 \%$ \\
\hline & Total & 35 & $100 \%$ \\
\hline
\end{tabular}

Sumber: Data primer (2016)

Tabel 2 di atas menunjukkan bahwa mayoritas peserta didik memiliki gaya belajar visual (34 \%), diikuti gaya belajar auditorial (14\%) dan kinestetik (7\%). Kemudian terdapat 3 orang peserta didik yang bergaya mix 1 (paduan visual-auditorial), 5 orang peserta didik yang bergaya mix 2 (paduan visual-kinestetik), 1 orang peserta didik 
yang bergaya mix 3 (paduan auditorial-kinestetik) serta 2 orang peserta didik yang bergaya mix 4 (paduan visual-Auditorial-kinestetik).

Untuk menghindari penafsiran yang berbeda serta memudahkan dalam penentuan gaya belajar yang tepat untuk diterapkan. Maka dalam penelitian ini, gaya belajar yang kita gunakan hanya visual, auditorial dan kinestetik (V-A-K). Maka peserta didik yang bergaya belajar mix, kita kelompokkan ke dalam gaya belajar yang dominan mereka gunakan berdasarkan atas jawaban yang diberikan pada kuesioner visual, auditorial dan kinestetik serta hasil observasi yang peneliti lakukan, sehingga tipe gaya belajar peserta didik pada bidang studi IPA Terpadu kelas VIII SMPN 6 Majene secara garis besar dapat dilihat dalam tabel 3 berikut.

Tabel 3 Gaya Belajar Peserta Didik Pada Bidang Studi IPA Terpadu

\begin{tabular}{|c|c|c|c|}
\hline No & Gaya Belajar & Frekuensi & Persentase \\
\hline 1. & Visual & 19 & $54 \%$ \\
\hline 2. & Auditorial & 7 & $20 \%$ \\
\hline 3. & Kinestetik & 9 & $26 \%$ \\
\hline \multicolumn{2}{|r|}{ Total } & 35 & $100 \%$ \\
\hline
\end{tabular}

Sumber: Data primer (2016)

Tabel 3 di atas menunjukkan bahwa peserta didik IPA Terpadu kelas VIII SMPN 6 Majene lebih dominan menggunakan gaya belajar visual dibandingkan tipe belajar yang lain. Hal ini dikarenakan peserta didik lebih mudah menyesuaikan diri dengan media atau alat peraga yang mereka gunakan seperti buku paket/bacaan, di samping itu metode pengajaran yang diterapkan di kelas juga turut mempengaruhi penentuan tipe gaya belajar peserta didik.

\subsection{Pembahasan}

Pada penelitian ini, didapatkan data bahwa terdapat tiga macam gaya belajar pada peserta didik bidang studi IPA Terpadu kelas VIII SMPN 6 Majene, meliputi gaya belajar visual, auditorial, dan kinestetik dengan jumlah terbanyak adalah peserta didik yang bergaya belajar visual. Ini dapat dilihat dari jumlah peserta didik secara berturut-turut yang bergaya belajar visual sebanyak 19 peserta didik sedangkan kinestetik ada 9 orang dan auditorial berjumlah 7 orang peserta didik.

Hal tersebut di atas menunjukkan bahwa seorang individu adalah pembelajar yang unik. Tidak ada dua orang yang persis sama dan tidak ada dua orang yang bisa belajar dengan cara yang sama. Adanya variasi gaya belajar pada peserta didik IPA Terpadu kelas VIII SMPN 6 Majene juga nampak melalui pengamatan langsung saat melakukan pengumpulan data pada sampel penelitian, respon atau sikap peserta didik pada saat pembagian lembar angket/kuesioner dan pemberian penjelasan pengisian angket serta saat mereka mengisi jawaban pada kuesioner tersebut itu sangat beragam. Ini menunjukkan bahwa gaya belajar merupakan suatu karakter bawaan, sehingga akan berbeda antara individu satu dengan yang lainnya. Sebagaimana pendapat yang dikemukakan oleh Gunawan (2012) yang menyatakan bahwa gaya belajar pada masingmasing individu merupakan karakter bawaan dan tidak dapat diubah, akan tetapi hanya dapat ditingkatkan dengan menerapkan cara belajar yang sesuai dengan gaya belajar yang ada pada dirinya. 
Hasil penelitian ini relevan dengan hasil penelitian yang dilakukan oleh Andriansyah (2010), Nihayah (2011), dan Amalina (2015). Hasil penelitiannya menunjukkan bahwa tiga macam gaya belajar semuanya ada pada peserta didik tetapi hanya ada satu gaya belajar yang dominan diantara tipe gaya belajar tersebut. Hasil penelitian ini juga mendukung teori learning style yang dikemukakan oleh DePotter dan Hernachi (2011) bahwa learning style diartikan sebagai gaya belajar yang dimiliki oleh setiap individu dimana merupakan cara termudah dalam menyerap informasi, mengatur dan mengolah informasi.

Tiap individu mempunyai gaya belajar atau learning style yang berbeda. Perbedaan ini sangat wajar. Tetapi harus disadari oleh individu yang bersangkutan, sehingga bisa dijadikan kelebihan untuk dikembangkan dalam meraih prestasi. Maka hendaknya menjadi perhatian bagi pihak sekolah untuk menjadikan faktor gaya belajar sebagai salah satu bahan pertimbangan dalam melaksanakan proses pembelajaran di SMP Negeri 6 Majene yang dapat memfasilitasi ketiga macam gaya belajar tersebut. Sebagaimana pendapat Kosasih dan Sumarna (2013) bahwa hasil belajar yang optimal akan diperoleh apabila beragam perbedaan seperti kebiasaan, minat dan gaya belajar pada peserta didik diakomodasi oleh guru/pihak penyelenggara pembelajaran melalui pilihan metode mengajar dan materi ajar yang sesuai dengan gaya belajar atau learning style peserta didik.

Perlu ditegaskan bahwa seseorang bukan berarti hanya memiliki salah satu karakteristik gaya belajar tertentu sehingga tidak memiliki karakteristik gaya belajar yang lain, pada dasarnya seseorang mempunyai ketiga modalitas tersebut namun biasanya ada salah satu karakteristik yang paling menonjol sehingga memudahkannya untuk menyerap pelajaran. Sehubungan dengan hal ini maka perlu kiranya bagi peserta didik untuk dapat beradaptasi dengan segala macam situasi, kondisi, maupun teknik mengajar para guru yang cenderung berbeda-beda dengan spesifikasi bidang ilmu yang diampunya.

\section{KESIMPULAN}

Berdasarkan hasil penelitian dan pembahasan dapat disimpulkan bahwa gaya belajar peserta didik pada bidang studi IPA Terpadu kelas VIII SMP Negeri 6 Majene secara keseluruhan menunjukkan bahwa gaya belajar visual yang paling banyak digunakan peserta didik yaitu sebesar $54 \%$, gaya belajar kinestetik sebesar $26 \%$ dan gaya belajar auditorial yang palimg rendah sebesar 20\%. Data ini menunjukkan bahwa seorang individu adalah pembelajar yang unik. Tidak ada dua orang yang persis sama dan tidak ada dua orang yang bisa belajar dengan cara yang sama.

\section{DAFTAR PUSTAKA}

Andriansyah. 2010. Hubungan antara Gaya Belajar dengan Hasil Belajar Siswa Pada Mata Pelajaran IPS SMP Islam YKS Depok (skripsi). Jakarta: Fakultas Ilmu Tarbiyah dan Keguruan UIN Syarif Hidayatullah.

DePorter, Bobbi dkk. 2011. Quantum Teaching. Bandung: Kaifa.

DePorter, B dan Hernacki, M. 2013. Quantum Learning. Bandung: Mizan Pustaka.

Gunawan, Adi W. 2012. Genius Learning Strategy. Jakarta: PT Gramedia Pustaka Utama.

Kosasih, N. dan Sumarna, D. 2013. Pembelajaran Quantum dan Optimalisasi Kecerdasan. Bandung: Alfabeta.

Margono. 2010. Metodologi Penelitian Pendidikan. Rineke Cipta. Jakarta. 
Nihayah, F. 2011. Profil Gaya Belajar (Learning Style) dan IPK Mahasiswa Jurusan Biologi FMIPA UNNES (skripsi). Semarang: Fakultas Matematika dan Ilmu Pengetahuan Alam Universitas Negeri Semarang.

Amalina, N. 2015. Pengaruh Gaya Belajar Terhadap Hasil Belajar Siswa Kelas IV SD Pajang 3 Surakarta Tahun Pelajaran 2014/201 (skripsi). Surakarta: Fakultas Keguruan dan Ilmu Pendidikan Universitas Muhammadiyah Surakarta.

Sardiman, A., M. 2014. Interaksi dan Motivasi Belajar Mengajar. Jakarta: PT. Raja Grafindo Persada.

Wahab, Abdul. 2012. Pengantar Riset. Yogyakarta: Kutub Wacana.

Zuriah, N. 2010. Metodologi Penelitian Sosial Dan Pendidikan: Teori Aplikasi. Jakarta: Bumi Aksara. 